\title{
ANALISIS KESESUAIAN PENYUSUNAN LAPORAN KEUANGAN DENGAN SAK- ETAP PADA KP-RI BINA KARYA DI BANYUWANGI TAHUN BUKU 2017
}

\author{
Laila Said Nadiyah ${ }^{1}$, Titin Kartini ${ }^{1}$, Sri Kantun ${ }^{1}$ \\ ${ }^{1}$ Program Studi Pendidikan Ekonomi, Fakultas Keguruan dan Ilmu Pendidikan, Universitas Jember \\ email : lailasaid617@gmail.com
}

\begin{abstract}
Abstrak
Penelitian ini bertujuan untuk menganalisis kesesuaian penyusunan laporan keuangan KP-RI BINA KARYA di Banyuwangi tahun buku 2017 dengan SAK-ETAP. Penentuan lokasi penelitian menggunakan metode purposive area. Metode pengumpulan data menggunakan metode dokumen dan wawancara. Metode penelitian menggunakan metode deskriptif dengan metode analisis data deskriptif evaluatif. Hasil analisis menunjukkan bahwa penyusunan laporan keuangan yang disusun oleh KP-RI BINA KARYA yakni neraca, laporan hasil usaha, laporan arus kas, laporan perubahan ekuitas dan catatan atas laporan keuangan sebagian besar telah sesuai dengan SAK-ETAP. Penyusunan neraca telah sesuai dengan standar ditinjau dari penyajian informasi, pengklasifikasian aset dan kewajiban, pengungkapan aset, kewajiban dan ekuitas. Laporan hasil usaha telah sesuai dengan standar ditinjau dari penyajian informasi, pengukuran dan pengungkapan pendapatan dan analisis beban yang digunakan. Laporan arus kas telah sesuai dengan standar dilihat dari penyajian informasi, arus kas operasi, investasi dan pendanaan serta pengungkapan komponen kas dan setara kas. Laporan perubahan ekuitas telah sesuai dengan standar dilihat dari penyajian informasi dan komponen laporan perubahan ekuitas. Catatan atas laporan keuangan juga telah sesuai dengan SAK-ETAP ditinjau dari struktur catatan dan pengungkapan kebijakan akuntansi yang digunakan. Terdapat beberapa ketidaksesuaian dalam penyusunan laporan keuangan koperasi yakni koperasi menambahkan laporan promosi ekonomi anggota yang tidak dipersyaratkan dalam SAK-ETAP kedalam laporan keuangannya, koperasi mengklasifikasikan persediaan tanah kedalam kategori aset lain-lain, terdapat ketidaksesuaian tarif penyusutan dengan perhitungan penyusutan salah satu aktiva tetap dan koperasi tidak mengungkapkan jatuh tempo dari utang usaha dan utang bank.
\end{abstract}

Kata Kunci: Laporan Keuangan, SAK-ETAP, KP-RI BINA KARYA

\section{PENDAHULUAN}

Laporan keuangan merupakan laporan yang menunjukkan kondisi keuangan suatu entitas atau badan usaha pada periode tertentu. Salah satu tujuan laporan keuangan adalah untuk memberikan informasi mengenai posisi keuangan hingga kinerja dari suatu badan usaha bagi berbagai pihak yang berkepentingan, baik itu pihak internal maupun pihak eksternal. Hery (2015:3) mengungkapkan bahwa laporan keuangan berfungsi sebagai alat informasi yang menghubungkan perusahaan dengan pihak-pihak yang berkepentingan dengan laporan keuangan perusahaan. Berdasarkan hal tersebut dapat dipahami bahwa laporan keuangan merupakan suatu hal yang penting dan harus dimiliki oleh setiap badan usaha.

Penyusunan laporan keuangan yang akan disajikan perlu disesuaikan dengan prinsip akuntansi yang berlaku di Indonesia (Effendi, 2014:7). Prinsip atau standar untuk akuntansi keuangan yang berlaku di Indonesia disusun dan disahkan oleh Dewan Standar Akuntansi Keuangan Ikatan Akuntan Indonesia (DSAK IAI). Ikatan Akuntan Indonesia (IAI) telah menerbitkan 4 standar akuntansi yang dapat digunakan sebagai acuan dalam kegiatan akuntansi perusahaan diantaranya adalah SAK Umum, Standar Akuntansi Syariah (SAS), Standar Akuntansi Keuangan Entitas Tanpa Akuntabilitas Publik (SAK-ETAP) dan Standar Akuntansi Keuangan Entitas Mikro, Kecil dan Menengah (SAK-EMKM). 
Laporan keuangan koperasi merupakan sistem dari pelaporan keuangan koperasi dan sebagai bentuk pertanggungjawaban pengurus tentang tata kehidupan koperasi (Sitio dan Tamba, 2001:107). Laporan keuangan koperasi merupakan bentuk pertanggungjawaban pengurus terhadap anggota koperasi, sehingga penyusunan laporan keuangan koperasi perlu disesuaikan dengan standar yang berlaku yakni SAK-ETAP. Standar tersebut bertujuan untuk mempermudah pelaksanaan kegiatan akuntansi dan penyusunan laporan keuangan. Standar akuntansi keuangan ini juga bertujuan untuk mempermudah suatu entitas untuk mendapatkan akses pendanaan secara lebih luas. Peraturan Menteri Koperasi dan UKM Nomor 12 tahun 2015 menyatakan bahwa koperasi sektor riil yang tidak memiliki akuntabilitas publik dipersyaratkan menyusun laporan keuangan berdasarkan SAK-ETAP yang terdiri dari neraca, laporan laba rugi, laporan arus kas, laporan perubahan ekuitas, dan catatan atas laporan keuangan.

KP-RI BINA KARYA, salah satu koperasi yang berada di Kabupaten Banyuwangi, telah menyusun laporan keuangan yang berupa neraca, laporan sisa hasil usaha, laporan arus kas, laporan perubahan ekuitas, laporan promosi ekonomi anggota dan catatan atas laporan keuangan. Berdasarkan hasil wawancara pra-penelitian, pengurus koperasi menyatakan telah menggunakan SAK-ETAP sebagai standar dalam penyusunan laporan keuangannya sejak tahun 2012.

Berdasarkan pemaparan permasalahan diatas, maka peneliti tertarik untuk melakukan analisis kesesuaian penyusunan laporan keuangan pada KP-RI BINA KARYA di Banyuwangi tahun buku 2017 dengan Standar Akuntansi Keuangan Entitas Tanpa Akuntabilitas Publik (SAK-ETAP).

\section{METODE}

Penelitian ini dilakukan di KP-RI BINA KARYA yang bertempat di Jl. Jenderal Ahmad Yani No. 45 Desa Jajag Kecamatan Gambiran Kabupaten Banyuwangi. Penelitian ini merupakan penelitian deskriptif dengan metode analisis deskriptif evaluatif. Penelitian akan dilakukan dengan pengumpulan data, dilanjutkan dengan penyajian data kemudian dianalisis kesesuaiannya dengan Standar Akuntansi Keuangan Entias Tanpa Akuntabilitas Publik (SAK ETAP). Data yang digunakan dalam penelitian ini yaitu data primer yang berupa laporan keuangan KP-RI BINA KARYA tahun buku 2017 (neraca, laporan sisa hasil usaha, laporan perubahan ekuitas, laporan arus kas dan catatan atas laporan keuangan) dan data sekunder yang berupa hasil wawancara terkait dengan kendala dalam penyusunan laporan keuangan, profil koperasi dan denah lokasi koperasi. Metode pengumpulan data yang digunakan yaitu metode dokumen dan wawancara.

\section{HASIL DAN PEMBAHASAN HASIL PENELITIAN}

Hasil penelitian ini meliputi kesesuaian penyusunan laporan keuangan KP-RI BINA KARYA tahun buku 2017 dengan SAK-ETAP yakni kelengkapan laporan keuangan koperasi berdasarkan Peraturan Menteri Koperasi dan UKM dan SAK-ETAP, kesesuaian penyusunan neraca, laporan hasil usaha, laporan perubahan ekuitas laporan arus kas dan catatan atas laporan keuangan berdasarkan standar akuntansi yang berlaku.

Laporan keuangan KP-RI BINA KARYA tahun buku 2017 telah disusun secara lengkap sesuai dengan Peraturan Menteri Koperasi dan UKM nomor 12 tahun 2015 yang mengacu pada SAKETAP. Laporan keuangan koperasi terdiri dari neraca, laporan hasil usaha, laporan perubahan ekuitas, laporan arus kas dan catatan atas laporan keuangan.

Penyusunan neraca KP-RI BINA KARYA secara umum sudah sesuai dengan ketentuan dalam SAK-ETAP. Neraca KP-RI BINA KARYA telah menyajikan informasi minimal yang harus disajikan dalam neraca sesuai dengan ketentuan SAK-ETAP. Neraca koperasi menyajikan informasi 
mengenai kelompok aset (aset lancar dan aset tidak lancar), kelompok kewajiban (kewajiban jangka pendek dan kewajiban jangka panjang) dan kelompok ekuitas. Koperasi juga telah mengungkapkan informasi yang berkaitan dengan neraca dalam catatan atas laporan keuangan mengenai klasifikasi atas pos yang disajikan yakni kelompok aset tetap, jumlah piutang usaha, persediaan barang, kelompok ekuitas.

Klasifikasi aset dan kewajiban KP-RI BINA KARYA telah sesuai dengan SAK-ETAP. Aset diklasifikasikan dalam aset lancar dan aset tidak lancer, urutan pos dalam aset disesuaikan berdasarkan likuiditasnya. Kewajiban diklasifikasikan menjadi kewajiban jangka pendek dan kewajiban jangka panjang. Koperasi menentukan urutan kewajiban berdasarkan periode jatuh temponya.

KP-RI BINA KARYA mengklasifikasikan aset sebagai aset lancar jika aset tersebut digunakan atau dipakai dalam waktu kurang dari satu periode. Aset lancar koperasi terdiri dari kas dan setara kas, piutang usaha, penyisihan piutang tak tertagih,persediaan barang dan biaya dibayar dimuka. Seluruh aset yang tidak termasuk kedalam kategori aset lancar, maka diklasifikasikan kedalam aset tidak lancar. Aset tidak lancar terdiri dari investasi jangka panjang, aset tetap, dan aset lain-lain. Aset lain-lain terdiri dari persediaan tanah dan hari tua karyawan. Koperasi mengungkapkan informasi tambahan terkait dengan aset yang dimiliki koperasi didalam catatan atas laporan keuangan koperasi sesuai dengan ketentuan SAK-ETAP.

KP-RI BINA KARYA mengklasifikasikan kewajiban sebagai kewajiban jangka pendek jika jatuh temponya kurang dari satu tahun. Kewajiban jangka pendek terdiri dari hutang usaha, simpanan sukarela, dana pembagian SHU, pajak yang masih harus dibayar, simpanan khusus dan simpanan tutup tahun. Kewajiban atau hutang pada koperasi dikategorikan sebagai hutang jangka panjang jika tidak memenuhi kriteria sebagai hutang jangka pendek yaitu jatuh temponya lebih dari satu tahun. Kewajiban jangka panjang terdiri dari simpanan khusus, simpanan hari tua karyawan dan hutang bank. Ekuitas pada KP-RI BINA KARYA terdiri dari simpanan wajib, modal penyertaan partisipasi anggota, donasi, cadangan umum, cadangan resiko dan SHU tahun berjalan. Koperasi telah mengungkapkan informasi tambahan terkait dengan kewajiban dan ekuitas koperasi didalam catatan atas laporan keuangan koperasi sesuai dengan ketentuan SAK-ETAP.

Penyusunan laporan hasil usaha KP-RI BINA KARYA telah sesuai dengan SAK-ETAP. Koperasi menyajikan informasi dalam laporan hasil usaha sesuai dengan ketentuan SAK-ETAP, yaitu: pendapatan (penjualan, pendapatan jasa, pendapatan kendaraan), HPP toko dan jasa (pembelian, potongan pembelian, retur pembelian, harga pokok pembelian, beban pembelian, harga pokok jasa, harga pokok kendaraan), beban usaha (beban pembinaan, administrasi, operasional dan penyusutan), pendapatan (beban) luar usaha, pajak penghasilan dan sisa hasil usaha (SHU).

KP-RI BINA KARYA mengukur setiap pendapatan yang ada pada koperasi sesuai dengan nilai pembayaran yang diterima secara tunai atau masih harus diterima oleh koperasi sesuai dengan standar yang berlaku. Nilai tersebut tidak termasuk jumlah diskon penjualan dan potongan volume. Koperasi juga mengungkapkan dalam catatan atas laporan keuangan tentang pengakuan pendapatan sebagai berikut: penjualan barang diakui saat penyerahan barang, pendapatan jasa simpan pinjam diakui secara akrual dan pendapatan jasa lainnya diakui saat penyerahan jasa. Koperasi juga telah menyajikan analisis beban sesuai dengan ketentuan yang dipersyaratkan oleh SAK-ETAP. Koperasi menyajikan analisis beban dan pendapatan dalam laporan hasil usaha berdasarkan fungsi beban. Berdasarkan metode analisis ini, beban dikumpulkan sesuai fungsinya sebagai bagian dari biaya penjualan atau sebagainya.

Penyusunan laporan arus kas KP-RI BINA KARYA telah sesuai dengan SAK-ETAP. Laporan arus kas disajikan dengan menggunakan metode tidak langsung. Laporan arus kas koperasi 
diklasifikasikan menurut aktivitas operasi, investasi dan pendanaan sesuai dengan ketentuan SAKETAP. Arus kas yang berasal dari aktivitas operasi terdiri dari transaksi yang mempengaruhi penetapan laba atau rugi. Aktivitas operasi koperasi menyajikan SHU tahun berjalan yang kemudian dikoreksi dengan transaksi non kas (penyisihan piutang tak tertagih dan penyusutan aset tetap) dan perubahan modal kerja (piutang usaha, persediaan barang, uang muka pembelian, biaya dibayar dimuka, hutang usaha, simpanan sukarela anggota, pembagian dana SHU, pajak yang masih harus dibayar, simpanan khusus, simpanan tutup tahun).

Arus kas aktivitas investasi KP-RI BINA KARYA mencerminkan pengeluaran kas sehubungan dengan sumberdaya yang bertujuan untuk menghasilkan pendapatan dan arus kas dimasa mendatang. Arus kas yang berasal dari aktivitas investasi terdiri dari perubahan investasi jangka panjang, perubahan aset tetap, perubahan aset lain-lain. Arus kas aktivitas pendanaan pada koperasi mencerminkan arus kas penerimaan dan pengeluaran yang berhubungan dengan sumber pendanaan untuk tujuan menghasilkan pendapatan masa depan. Arus kas yang berasal dari aktivitas pendanaan koperasi ini berasal dari perubahan: kewajiban jangka panjang, simpanan pokok, simpanan wajib, modal penyertaan partisipasi anggota, modal penyertaan, donasi, cadangan umum, cadangan resiko dan alokasi SHU tahun lalu.

KP-RI BINA KARYA menyajikan komponen kas dan setara kas koperasi sesuai dengan ketentuan SAK-ETAP. Kas dan setara kas dalam hal ini merupakan uang tunai dan simpanan di bank yang dimiliki oleh koperasi. Kas dan setara kas digunakan untuk menjaga likuiditas koperasi. Koperasi juga telah mengungkapkan dalam catatan atas laporan keuangan komponen kas dan setara kas dan telah menyajikan rekonsiliasi jumlah yang dilaporkan dalam laporan arus kas dengan pos yang sama yang disajikan dalam neraca.

Penyusunan laporan perubahan ekuitas KP-RI BINA KARYA telah sesuai dengan SAKETAP. Laporan perubahan ekuitas yang disusun oleh KP-RI BINA KARYA menyajikan informasi mengenai sisa hasil usaha untuk periode 2017 dan rekonsiliasi antara jumlah yang tercatat pada awal dan akhir periode untuk setiap komponen ekuitas, yang menunjukkan perubahan secara terpisah dari : sisa hasil usaha, simpanan pokok, simpanan wajib, modal penyertaan partisipasi anggota, modal penyertaan, donasi, cadangan umum, cadangan resiko, alokasi SHU. Komponen laporan perubahan ekuitas KP-RI BINA KARYA menunjukkan perubahan baik itu penambahan maupun pengurangan dari ekuitas. Perubahan ekuitas berasal dari dari sisa hasil usaha, simpanan pokok, simpanan wajib, modal penyertaan partisipasi anggota, modal penyertaan, donasi, cadangan umum, cadangan resiko dan sisa hasil usaha yang tidak dibagikan pada periode akuntansi.

Penyusunan catatan atas laporan keuangan KP-RI BINA KARYA telah sesuai dengan SAKETAP. Catatan atas laporan keuangan koperasi menyajikan informasi tentang dasar akuntansi dalam penyusunan laporan keuangan dan kebijakan akuntansi tertentu yang digunakan, mengungkapkan informasi yang disyaratkan SAK-ETAP tapi tidak disajikan dalam laporan keuangan, memberikan informasi tambahan yang tidak disajikan dalam laporan keuangan tapi relevan untuk memahami laporan keuangan seperti metode perhitungan persediaan, penyisihan piutang, aset tetap, sisa hasil usaha dan sebagainya. Catatan atas laporan keuangan disajikan secara sistematis sesuai dengan kaidah SAK-ETAP. Setiap pos dalam laporan keuangan baik itu neraca maupun laporan hasil usaha merujuk silang pada Catatan atas laporan keuangan.

Urutan penyajian catatan atas laporan keuangan KP-RI BINA KARYA adalah dasar akuntansi yang digunakan, pernyataan bahwa laporan keuangan disusun sesuai dengan SAK-ETAP, pernyataan bahwa laporan keuangan dilampiri dengan laporan promosi ekonomi anggota, dasar penyajian laporan keuangan, ringkasan kebijakan akuntansi yang diterapkan dan dilanjutkan dengan pengungkapan informasi yang mendukung pos-pos pada laporan keuangan. Catatan atas laporan keuangan koperasi 
juga telah menyajikan ringkasan kebijakan akuntansi yang mengungkapkan dasar pengukuran yang digunakan dalam penyusunan laporan keuangan dan kebijakan akuntansi lain yang digunakan yang relevan untuk memahami laporan keuangan sesuai dengan ketentuan SAK-ETAP.

\section{PEMBAHASAN}

Terdapat beberapa ketidaksesuaian dalam penyusunan laporan keuangan KP-RI BINA KARYA. Ketidaksesuaian pertama yaitu koperasi menyajikan laporan promosi ekonomi anggota yang tidak dipersyaratkan dalam SAK-ETAP sebagai bagian dari laporan keuangan. Koperasi perlu menyajikan laporan keuangan lengkap sesuai dengan SAK-ETAP yang terdiri dari neraca, perhitungan hasil usaha, laporan arus kas, laporan perubahan ekuitas dan catatan atas laporan keuangan (Effendi, 2014). Standar tersebut tidak mencantumkan laporan promosi ekonomi kedalam laporan keuangan yang harus disusun oleh koperasi. Pihak KP-RI BINA KARYA menyatakan bahwa laporan promosi ekonomi anggota perlu disajikan dalam laporan keuangan agar anggota dapat mengetahui manfaat ekonomi yang didapatkan dengan menjadi anggota koperasi. Hal ini sesuai dengan pernyataan kasubbag akuntansi KP-RI BINA KARYA.

"Laporan promosi ekonomi anggota disusun agar anggota tahu perkembangan keuangan dari koperasi, agar anggota dapat mengetahui manfaat ekonomi yang didapatkan dengan menjadi anggota koperasi jika dibandingkan dengan lembaga keuangan yang lain, dan agar tidak ada keraguan dari anggota”. (Supiyah, 54).

Koperasi juga menyatakan dalam Catatan atas laporan keuangan pada bagian kebijakan akuntansi bahwa laporan keuangan dilampiri dengan laporan promosi ekonomi anggota dengan tujuan untuk mengetahui sejauh mana manfaat koperasi bagi anggota jika dibandingkan dengan lembaga keuangan yang ada di sekitar daerah kerja KP-RI BINA KARYA.

Ketidaksesuaian selanjutnya adalah adanya kesalahan dalam penyajian dan akun-akun dalam laporan keuangan. Kesalahan tersebut terletak pada penyajian serta pengungkapan beberapa pos dalam neraca, diantaranya adalah persediaan tanah, aset tetap, utang usaha dan utang bank. Koperasi mengklasifikasikan persediaan tanah kedalam aset tidak lancar, kategori aset lain-lain, hal ini kurang sesuai dengan SAK-ETAP. Persediaan tanah tidak digunakan untuk penyediaan barang maupun kegiatan operasional koperasi sehingga tidak termasuk kedalam aset tetap dan masuk ke kategori aset lain-lain. Hal ini sesuai dengan pernyataan kasubbag akuntansi KP-RI BINA KARYA.

"Persediaan tanah masuk ke dalam kategori aset lain-lain karena persediaan tanah tidak digunakan dalam operasional koperasi dan tidak termasuk kedalam aset tetap. Persediaan tanah masuk ke kategori pos aset lain-lain karena termasuk untuk investasi dan kemungkinan beberapa tahun yang akan datang akan dijual kembali." (Supiyah, 54).

Berdasarkan keterangan kasubbag akuntansi KP-RI BINA KARYA terkait dengan pengertian dari persediaan tanah diatas, seharusnya pos ini tidak masuk kedalam kategori aset lain-lain. Persediaan tanah termasuk kedalam kategori investasi jangka panjang, investasi jangka panjang secara umum melibatkan aset berwujud seperti tanah, mesin-mesin atau pabrik (Fahmi dan Hadi, 2009:7). Penyajian pos persediaan tanah di dalam neraca seharusnya termasuk kedalam kategori properti investasi karena merupakan properti berupa tanah dan dimiliki untuk kenaikan nilai dimasa mendatang sesuai dengan pengertian properti investasi menurut SAK-ETAP (2018:47) nomor 14.2.

Ketidaksesuaian selanjutnya terkait dengan tarif penyusutan aktiva tetap. Menurut SAKETAP (2018:53) nomor 15.31(c) entitas harus mengungkapkan umur manfaat dan tarif penyusutan aktiva tetap. KP-RI BINA KARYA menggunakan metode garis lurus dalam penyusutan aktiva tetapnya dan koperasi telah mencantumkan umur manfaat dari masing-masing aktiva tetap. Pihak koperasi telah melakukan perhitungan penyusutan aktiva tetap, tetapi tidak dicantumkan didalam laporan keuangan. Hal ini sesuai dengan pernyataan kasubbag akuntansi KP-RI BINA KARYA. 
"Sebenarnya ada perhitungan penyusutan aktiva tetapnya, tetapi memang tidak dicantumkan dalam laporan keuangan, yang dicantumkan dalam laporan keuangan adalah umur ekonomis dan nilai beban penyusutan aktiva tetap. Penyusutan aktiva tetap menggunakan metode garis lurus untuk bangunan 5\%, untuk kendaraan roda 4 (ELF) 12,5\%, untuk kendaraan roda 2 $12,5 \%$, untuk peralatan 25\%" (Supiyah,54).

KP-RI BINA KARYA telah mengungkapkan umur manfaat dari masing-masing aktiva tetap, tetapi masih kurang sesuai dengan tarif penyusutan yang dinyatakan oleh kasubbag akuntansi misalnya terkait dengan umur manfaat peralatan yang diungkapkan dalam catatan atas laporan keuangan adalah 4 tahun sehingga tarif penyusutan peralatan harusnya $25 \%$, tetapi pada realisasinya tarif penyusutan salah satu peralatan yakni brankas adalah $12,5 \%$.

Ketidaksesuaian yang selanjutnya adalah terkait dengan pengungkapan jatuh tempo kewajiban jangka pendek dan kewajiban jangka panjang. Hal ini sesuai dengan pernyataan kasubbag akuntansi KP-RI BINA KARYA.

"Jatuh tempo utang tidak dicantumkan karena kalau hutang jangka pendek (hutang usaha) itu jatuh temponya 1 bulan, jika bulan ini transaksi maka dibayar bulan depan. Kalau hutang jangka panjang seperti hutang bank, jatuh temponya 3 tahun.” (Supiyah, 54)

KP-RI BINA KARYA tidak mencantumkan jatuh tempo dari kewajiban khususnya utang usaha dan utang bank jatim dalam laporan keuangan karena pihak koperasi sudah mengetahui jatuh tempo dari utang tersebut. Penyajian tersebut mungkin sudah cukup bagi pihak koperasi, namun informasi ini kurang relevan untuk memahami informasi terkait dengan jatuh tempo utang bagi pihak yang berkepentingan diluar koperasi. Informasi dalam laporan keuangan akan bermanfaat apabila informasi tersebut dapat dipahami oleh para pengguna laporan keuangan (Kartikahadi dkk,. 2012:49). Hal ini sesuai dengan SAK-ETAP (2018:3) nomor 2.2 kualitas penting informasi yang disajikan dalam laporan keuangan adalah kemudahannya untuk segera dapat dipahami oleh pengguna.

\section{PENUTUP}

Berdasarkan hasil penelitian dan pembahasan, dapat disimpulkan bahwa penyusunan laporan keuangan KP-RI BINA KARYA tahun buku 2017 sebagian besar sudah sesuai dengan SAK ETAP. Hal ini dapat dibuktikan dari KP-RI BINA KARYA telah menyajikan laporan keuangan secara lengkap sesuai dengan ketentuan SAK-ETAP. Penyusunan neraca telah sesuai dengan standar yang berlaku ditinjau dari penyajian informasi, pengklasifikasian aset dan kewajiban, pengungkapan aset, kewajiban dan ekuitas. Penyusunan laporan hasil usaha telah sesuai dengan standar ditinjau dari penyajian informasi, pengukuran dan pengungkapan pendapatan dan analisis beban yang digunakan. Penyusunan laporan arus kas telah sesuai dengan standar yang berlaku dilihat dari informasi yang disajikan, arus kas operasi, investasi, pendanaan serta pengungkapan komponen kas dan setara kas. Penyusunan laporan perubahan ekuitas telah sesuai dengan standar dilihat dari informasi yang disajikan dan komponen laporan perubahan ekuitas. Penyusunan catatan atas laporan keuangan juga telah sesuai dengan SAK-ETAP ditinjau dari struktur dan pengungkapan kebijakan akuntansi yang digunakan oleh koperasi. Meskipun ada beberapa ketidaksesuaian terkait dengan pengklasifikasian akun dan pengungkapan informasi dalam laporan keuangan, penyusunan seluruh komponen laporan keuangan sudah sesuai dengan kaidah SAK ETAP.

Beberapa ketidaksesuaian dalam penyusunan laporan keuangan KP-RI BINA KARYA yakni KP-RI BINA KARYA menambahkan laporan promosi ekonomi anggota yang tidak dipersyaratkan dalam SAK-ETAP kedalam laporan keuangannya dengan tujuan agar anggota dapat mengetahui manfaat ekonomi yang didapatkan dengan menjadi anggota koperasi, koperasi mengklasifikasikan 
persediaan tanah kedalam kategori aset lain-lain, terdapat ketidaksesuaian tarif penyusutan dengan perhitungan penyusutan salah satu aktiva tetap dan koperasi tidak mengungkapkan jatuh tempo dari utang usaha dan utang bank.

Berdasarkan penelitian yang telah dilakukan penulis dapat memberikan saran kepada pengurus KP-RI BINA KARYA terkait dengan penyusunan laporan keuangan berdasarkan SAKETAP. Koperasi dapat terus konsisten menyusun laporan keuangan yang sesuai dengan standar yang berlaku bagi koperasi yakni SAK-ETAP. Serta dapat mematuhi segala peraturan yang telah ditetapkan oleh standar tersebut. Koperasi dapat menyajikan informasi dalam laporan keuangan secara lebih lengkap sesuai dengan SAK-ETAP dalam penyusunan laporan keuangan untuk periode selanjutnya.

\section{DAFTAR PUSTAKA}

Effendi, Rizal. 2014. Accounting Principles: Prinsip-prinsip Akuntansi Berbasis SAK ETAP. Jakarta : PT Raja Grafindo Persada.

Hery. 2015. Analisis Laporan Keuangan. Jakarta: PT. Grasindo

Ikatan Akuntan Indonesia. 2018. Standar Akuntansi Keuangan Entitas Tanpa Akuntabilitas Publik. Jakarta: Ikatan Akuntan Indonesia

Kartikahadi, H., R.U. Sinaga, M. Syamsul, dan S.V. Siregar. 2012. Akuntansi Keuangan Berdasarkan SAK berbasis IFRS. Jakarta Selatan : Salemba Empat

Rudianto. 2012. Pengantar Akuntansi. Jakarta: Erlangga

Sitio, A dan H. Tamba. 2001. Koperasi: Teori \& Praktik. Jakarta: Erlangga.

Peraturan Menteri Koperasi dan Usaha Kecil dan Menengah Nomor 12 tahun 2015 tentang Pedoman Umum Akuntansi Sektor Riil. 